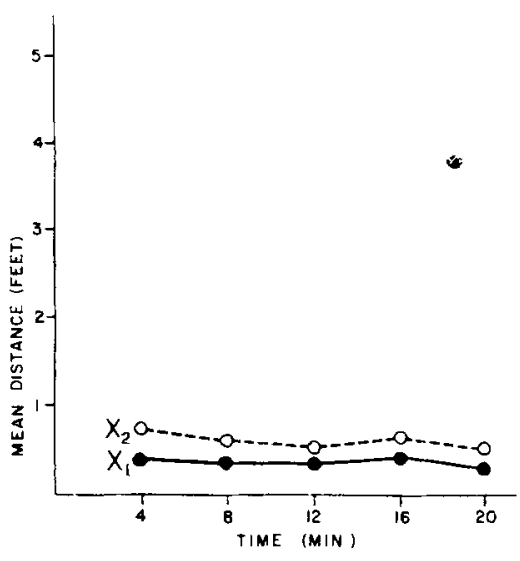

Fig. 3. Mean distance between Monkeys $X 1$ and $Y 1, Y 2, Y 3$, and $Y 4$ combined and Monkeys $X 2$ and $Y 1, Y 2, Y 3$, and $Y 4$ combined, after 6 months' confinement.

Cairns's (1966) hypothesis that "the strength of S's attachment with respect to $\mathrm{O}_{\mathrm{a}}$ should be inversely related to the length of separation from $\mathrm{O}_{a}$ " where $\mathrm{O}_{a}$ is the object of attachment. These results indicate that the length of confinement in cages for experimental studies on social behavior in monkeys should be explicitly taken in to account.

\section{REFERENCES}

CAIRNS, R. S. Attachment behavior of mammals. Psychological Review, 1966, 73, 409-426.

JOSLYN, W. D. Behavior of socially experienced juvenile rhesus monkeys after eight months of late social isolation and maternal separation in juvenile rhesus monkeys. Unpublished doctoral dissertation, Unviersity of Wisconsin, 1968.

MASON, W. A. The effects of social restriction on the behavior of rhesus monkeys: $I$. Free social behavior. Journal of Comparative \& Physiological Psychology, 1960, 53, 582-589. MASON, W. A. The effects of social restriction on the behavior of rhesus monkeys: II. Tests of gregariousness. Journal of Comparative \& Physiological Psychology, 1961, 54, 287-290.

MASON, W. A. The effects of social restriction on the behavior of rhesus monkeys: III. Dominance tests. Journal of Comparative \& Physiological Psychology, 1961, 54, 694-699. MOYER, K. E., \& KORN, J. H. Behavioral effects of isolation in the rat. Psychonomic Science, 1965, 3, 503-504.

SALAZAR, J. M. Gregariousness in young rats. Psychonomic Science, 1968, 10, 391-392.

\title{
Inescapable shocks and subsequent escape/avoidance conditioning in goldfish. Carassius auratus
}

\section{A. M. PADILLA, CHRISTINE PADILLA, TERRY KETTERER, and DIANE GIACALONE \\ State University of New York, Potsdam, N.Y. 13676}

Two experiments were conducted with goldfish, Carassius auratus, to assess the effects of inescapable shocks on subsequent escape/avoidance conditioning. Results indicate that inescapable shock presentations interfere with later avoidance training when Ss are tested 0,24 , and $48 \mathrm{~h}$ following inescapable shocks. However, the interference effect dissipates with time so that in $72 \mathrm{~h}$ Ss are capable of avoiding shock. The findings confirm the cross-species generality of the interference effect.

Overmier \& Seligman (1967) and Seligman \& Maier (1967) have shown that inescapable shocks interfere with the subsequent escape/avoidance conditioning of dogs. The interference effect has been obtained under a variety of shock parameters and with signaled and unsignaled inescapable shocks. Further, learning is not impaired if 48 to $72 \mathrm{~h}$ intervene between inescapable shocks and avoidance training (Overmier, 1968; Overmier \& Seligman, 1967).

Maier, Seligman, \& Solomon (1969) attribute the findings of depressed avoidance learning following inescapable shocks to learned helplessness. According to this interpretation, Ss' lack of control over the inescapable shocks results in a condition of helplessness. Indirect support for the generality of the interference effect has been shown across a wide variety of species (Maier et al, 1969).

The purpose of the present experiments was to extend the findings of Overmier and Seligman to a species considerably different from dogs. Specifically, the intent of the research was (1) to determine if the interference effect could be obtained with goldfish and (2) to investigate the time course of such an effect.

\section{EXPERIMENT 1}

The purpose of this experiment was to determine whether goldfish, given inescapable shocks, show a reduced rate of avoidance responding in a test session given $24 \mathrm{~h}$ after inescapable shocks.

Subjects and Apparatus

Thirty experimentally naive goldfish (Carassius auratus), 2-3 in. in length, were used. Ss were obtained from a local dealer and housed in a 55-gal tank for 1 week prior to the experiment.

Two Lafayette aquatic shuttlebox avoidance apparatuses (Model No. A-660) with the associated programmer timers and shock-generating control consoles were used. The shock level was set at $28 \mathrm{~V}$.

Procedure

Ss were randomly assigned to one of two groups ( $N=15$ per group). $S s$ in the experimental group were given 2 days of training. On Day 1 Ss were confined to one compartment of the apparatus and, following a 15-min adaptation period, were given 60 presentations of unsignaled and inescapable shock. Each shock was of $5 \mathrm{sec}$ duration. The interstimulus interval was $55 \mathrm{sec}$. Following inescapable shocks Ss were removed from the apparatus, returned to the storage tank, and confined in individual aquatic breeder nets. Approximately $24 \mathrm{~h}$ later Ss were given 25 trials of avoidance conditioning training. During this phase of the experiment, the shuttlebox was programmed so that the CS (light) preceded the US (shock) by $10 \mathrm{sec}$. If $S$ successfully avoided the US by swimming from the CS-on compartment to the safe compartment, the CS was manually terminated. If $S$ failed to avoid, the US was programmed for $5 \mathrm{sec}$. An escape response terminated both the CS and US. If $S$ failed to escape, the CS-US terminated automatically. The onset of each trial occurred $60 \mathrm{sec}$ after the onset of the CS on the preceding trial, regardless of whether $S$ had successfully avoided or escaped the US.

Ss in the second group served as controls. These Ss were given 25 trials of avoidance training only. $S s$ in both conditions were allowed $15 \mathrm{~min}$ of adaptation to the shuttlebox apparatus prior to any avoidance training.

\section{Results}

Table 1 summarizes the avoidance performance data. Analyses revealed that the control Ss differed significantly from the experimental $\mathrm{Ss}$ both in mean avoidance responses and mean number of trials to the first avoidance response $(t=4.62$ and 3.98 , respectively, $\mathrm{d} f=28$, $p<.01)$. However, the two groups did not 
Table 1

Indexes of Acquisition

\begin{tabular}{|c|c|c|c|}
\hline Group & $\begin{array}{l}\text { Mean } \\
\text { Avoid- } \\
\text { ance } \\
\text { Responses }\end{array}$ & $\begin{array}{l}\text { ean Number } \\
\text { of Trials } \\
\text { to First } \\
\text { Avoid- } \\
\text { ance }\end{array}$ & $\begin{array}{c}\text { Mean } \\
\text { Median } \\
\text { Latency } \\
\text { (in } \\
\text { Seconds) }\end{array}$ \\
\hline & \multicolumn{3}{|c|}{ Experiment I } \\
\hline Control & 11.0 & 3.9 & 10.30 \\
\hline \multirow[t]{2}{*}{ Experimenta } & 2.9 & 14.4 & 13.90 \\
\hline & \multicolumn{3}{|c|}{ Experiment 2} \\
\hline Control & 11.3 & 2.8 & 9.70 \\
\hline $0 \mathrm{~h}$ & 3.9 & 13.0 & 14.15 \\
\hline $24 \mathrm{~h}$ & 3.4 & 5.7 & 13.80 \\
\hline $48 h$ & 6.0 & 5.3 & 12.75 \\
\hline $72 \mathrm{~h}$ & 12.2 & 3.0 & 9.65 \\
\hline
\end{tabular}

differ in their latency data $(\mathrm{t}=1.32$, $\mathrm{df}=28, \mathrm{p}>.05$ ).

\section{EXPERIMENT 2}

Since an interference effect was obtained in Experiment 1, the purpose of this study was to extend the earlier findings by assessing the time course of the effect.

\section{Subjects and Apparatus}

Ss were 50 experimentally naive goldfish of the same size and obtained from the same source as in Experiment 1. All Ss were housed in a 55-gal tank for 3 weeks prior to the start of the experiment.

The same two Lafayette aquatic avoidance apparatuses used in Experiment 1 were employed. Programming of the shuttleboxes was the same as in the earlier study.

Procedure

Ss were randomly assigned to one of five groups $(\mathrm{N}=10$ per group). Four of the groups were given 60 presentations of unsignaled inescapable shock on Day 1 and, following $0,24,48$, or $72 \mathrm{~h}$, were given 25 trials of avoidance training. The procedure of inescapable shocks was the same as in Experiment 1. Ss in the control group received 25 trials of avoidance training only.

\section{Results}

Table 1 contains a summary of avoidance learning for $S s$ in this experiment. As can be seen in the table, an interference effect was obtained in the avoidance learning of the $0 \cdot, 24$, and $48-\mathrm{h}$ conditions but had dissipated after approximately $72 \mathrm{~h}$. Analyses of variance showed that the groups differed significantly in mean avoidance responses
$(\mathrm{F}=11.12, \mathrm{df}=4 / 45, \mathrm{p}<.001)$ and trials to the first avoidance response $(\mathrm{F}=5.03$, $\mathrm{df}=4 / 45, \mathrm{p}<.01)$, but not in their latency measure $(\mathrm{F}=1.33, \mathrm{df}=4 / 45$, $\mathrm{p}>.05$ )

Paired comparisons further indicated that both the control and $72 \cdot \mathrm{h}$ groups differed reliably $(p<.01)$ from the other treatment conditions in their mean avoidance responses. However, the control Ss and the 72-h group did not differ from each other; similarly, the 0-, 24-, and 48-h experimental conditions did not differ from each other.

In terms of the other two dependent measures, individual comparisons revealed that the 0 -h treatment group differed significantly $(\mathrm{t}=2.69$ and $2.40, \mathrm{df}=28$, $\mathrm{p}<.05$ ) from both the control and $72-\mathrm{h} \mathrm{Ss}$ in mean number of trials to the first avoidance response. None of the other comparisons attained statistical reliability.

\section{DISCUSSION}

These studies show that inescapable shocks interfere with subsequent escape/avoidance conditioning in goldfish. The findings concur with the results discussed by Maier et al (1969) when dogs were the experimental Ss. In addition to a general interference effect, the results of Experiment 2 suggest that the time course of the effect is similar to that reported with dogs. Overmier \& Seligman (1967) reported that their Ss had fully recovered from the interference effect after $48 \mathrm{~h}$, whereas Overmier (1968) reported that his Ss required approximately $72 \mathrm{~h}$ before good avoidance conditioning was demonstrated.

Both the results reported here and those reported by Overmier are compatible with the findings of McAllister \& McAllister $(1962,1963)$ with rats, which show that inescapable shocks do not interfere with escape/avoidance responding if a delay intervenes between the two sessions. However, there is some question about the length of such a delay, since McAllister and McAllister report avoidance responding after $24 \mathrm{~h}$, whereas Overmier and Seligman report a necessary delay of $48 \mathrm{~h}$. Overmier (1968) and the results reported here imply that a 72 -h delay is necessary.

Two interpretations have been offered to account for the interference effect. Maier et al (1969) have employed a learned helplessness interpretation that is based on the S's lack of control over inescapable shock. McAllister and McAllister have attributed the effect to competing instrumental responses acquired during inescapable shock presentations. Despite the difference in interpretation, however, the question of why the interference effect dissipates with time remains unclear. Overmier and Seligman have suggested that the effect is associated with a parasympathetic reaction which dissipates with time, while McAllister \& McAllister (1962, 1963), using rats as Ss, have suggested that the effect is based on the disruption of emotionality. Whether these two accounts differ substantially remains to be seen. Of more importance is the cross-species generality of the effect of inescapable shocks on subsequent escape/avoidance learning and the time course of the effect.

The extension of the results reported by Overmier and Seligman and their associates to a phyletic level, for which little data are available, and to an organism whose reactions to shock differ considerably from dogs confirms the generality of the interference effects

\section{REFERENCES}

MAIER, S. F., SELIGMAN, M. E. P., \& SOLOMON, R. L. Pavlovian fear conditioning and learned helplessness: Effects on escape and avoidanse behavior of (a) the CS-US contingency and (b) the independence of the US and voluntary responding. In B. A. Campbell and R. M. Church (Eds.), Punishment and aversive behavior. New York: Appleton-Century-Crofts, 1969. Pp. 299-342.

MCALLISTER, W. R., \& McALLISTER, D. E Postconditioning delay and intensity of shock as factors in the measurement of acouired fear. Journal of Experimental Psychology, 1962, 64, 110-116.

MCALLISTER, W. R., \& MCALLISTER, D. E. Increase over time in the stimulus generalization of acquired fear. Journal of Experimental Psychology, 1963, 65, 576-582. OVERMIER, J. B. Interference with avoidance behavior. Failure to avoid traumatic shock. Joumal of Experimental Psychology, 1968, $78,340-343$

OVERMIER, J. B., \& SELIGMAN, M. E. P. Effects of inescapable shock upon subsequent escape and avoidance responding. Journal of Comparative \& Physiological Psychology, $1967,63,28-33$

SELIGMAN, M. E. P., \& MAIER, S. F. Failure to escape traumatic shock. Journal of Experimental Psychology, 1967, 74, 1-9. 